\title{
Tuberculosis in childhood: a systematic review of national and international guidelines
}

\author{
Elettra Berti, Luisa Galli, Elisabetta Venturini, Maurizio de Martini, Elena Chiappini*
}

\begin{abstract}
Background: Paediatric tuberculosis (TB) represents a major public health concern worldwide. About 1 million children aged less than 15 years develop TB each year, contributing to $3-25 \%$ of the total TB caseload. The aim of this review is to evaluate national and international guidelines concerning tuberculosis in childhood and compare them in terms of diagnosis and treatment strategies.

Methods: A literature search of the Pubmed database was performed from January 2000 to August 2013, using the terms "tuberculosis" and "children". The search was limited to guidelines and consensus conferences, human species and full text availability, with no language restrictions.
\end{abstract}

Results: Twenty-seven national and international guidelines are identified. Several discrepancies on the diagnosis workup of TB are underlined. The main points of disagreement are represented by the interpretation of tuberculin skin test (TST) result and the recommendations on the use of TST and/or interferon-gamma release assay (IGRA) for the diagnosis of TB infection. Otherwise, all guidelines are in agreement that a microbiological confirmation should always be sought. Similarly, susceptibility drug testing and genotyping should be performed whenever it is possible on the basis of resources availability. On the contrary, the use of nucleic acid amplification tests (NAATs) for the M. tuberculosis detection is still controversial. A general consensus exists, otherwise, on TB treatment and only minor discrepancies are evidenced, such as the recommendations on daily or intermittent treatment regimens.

Conclusions: Despite advances in TB diagnostic tools have been reached during the last decade, a lack of uniformity in their availability, indication and interpretation has relevant consequences for clinical practice. Further studies need to be performed to clarify this issue and identify a reliable and reproducible diagnostic workup. Moreover, future studies should analyze the drug metabolism and the efficacy of intermittent dosing regimes in childhood, as well as new treatment regimens in order to improve the therapy compliance.

\section{Background}

Paediatric tuberculosis (TB) represents a major public health concern worldwide. The World Health Organization (WHO) reported that about 9 million people develop TB each year, and of whom about 1 million (11\%) occur in children aged less than 15 years. Children contribute to $3-6 \%$ of the total TB caseload in developed countries and to more than $25 \%$ of the burden of TB disease in developing countries [1]. Nonetheless, paediatric TB has been relatively neglected for several years, mainly due to difficulties in mycobacterium isolation in children. Novel developments in diagnosis and treatment of paediatric TB

\footnotetext{
*Correspondence: elena.chiappini@unifi.it

Department of Health Sciences, Meyer Children University Hospital, University of Florence, Florence, Italy
}

(c) 2014 Berti et al; licensee BioMed Central Ltd. This is an Open Access article distributed under the terms of the Creative Commons Attribution License (http://creativecommons.org/licenses/by/2.0), which permits unrestricted use, distribution, and reproduction in any medium, provided the original work is properly cited. The Creative Commons Public Domain Dedication waiver (http:// creativecommons.org/publicdomain/zero/1.0/) applies to the data made available in this article, unless otherwise stated. have been carried out and, more recently, the definition of an adequate management of TB in childhood has become one of the main aspects of the global TB control efforts [1-4].

The aim of the present systematic review is to evaluate and compare national and international guidelines concerning diagnosis and treatment strategies in paediatric TB.

\section{Methods}

A literature search of the Pubmed database was performed from January 2000 to August 2013, using the terms "tuberculosis" and "children" as key words. The search was limited to type of article, guideline and consensus conference, human species and full text availability, with 
no limits of language. The results were also restricted on the basis of title and abstract. Therefore, 23 articles were identified and of those 17 were considered relevant to the goal of the research.

In order to verify the completeness of the Pubmed database, a literature search of other databases (Web of Science, Embase, Pascal and National Guideline Clearinghouse) was also conducted, but the results were virtually overlapping.

Additionally, the websites of relevant government organizations and professional societies were reviewed for documents of interest (WHO, Center for Disease Control and Prevention - CDC, European Center for Disease Control and Prevention - ECDC, National Institute for Health and Care Excellence - NICE, American Academy of Pediatrics - AAP, International Union Against Tuberculosis and Lung Disease - IUATLD, American Thoracic Society - ATS, Canadian Thoracic Society - CTS). All reference lists were examined in order to identify pertinent publications, which were added in the review.

All the results were closely evaluated and the papers that were not pertinent or redundant were excluded. In particular, our search was limited to guidelines developed at national or international levels, excluding local or regional recommendations, and overall 27 articles were included in this review.

\section{Results}

The twenty-seven guidelines identified through the search strategy are listed in table 1 . Twelve guidelines regard exclusively paediatric TB [1,5,9-12,23-26,28-30], whereas 15 guidelines analyze the management of TB in both adults and children [6-8,13-22,27,31]. The majority of the guidelines were focused on restricted fields concerning paediatric TB, as diagnostic tools or treatment strategies, whereas eight guidelines discuss extensively all aspects related to the management of $\mathrm{TB}$ in childhood $[1,9,12,18,22,28,29,31]$.

\section{Diagnostic tests for $M$. tuberculosis infection}

The demonstration of $M$. tuberculosis infection is a relevant part of the diagnosis of both TB disease and latent TB infection (LTBI). LTBI is defined as M. tuberculosis complex infection without clinical features or radiographic findings of TB disease $[1,12,21,29]$. Children with LTBI are at increased risk of developing active $\mathrm{TB}$ and becoming infectious. Therefore the identification of children latently infected with $M$. tuberculosis represents an important issue of TB preventive strategies.

Tuberculin skin test (TST) and interferon-gamma release assays (IGRAs) are immune-mediated methods currently available for identifying $M$. tuberculosis infection $[1,6,9-12,14,16,19,21-23,28,29,31]$. However, TST and
IGRA are not able to distinguish between latent TB infection and active disease, and a negative result does not exclude the possibility of $M$. tuberculosis infection . Therefore, according to the AAP [12], both TST and IGRAs should not be considered a gold standard for the diagnosis of LTBI.

The TST is based on the evidence that M. tuberculosis infection promotes a delayed-type hypersensitivity reaction to antigenic components isolated from tubercle bacilli culture by protein precipitation (PPD), also known as tuberculin. All guidelines recommend that TST should be performed only in children who are at increased risk of $M$. tuberculosis infection (i.e. contact with people with contagious TB, HIV-infected children) or children with suspected TB disease. The preferred method of PPD administration is represented by Mantoux technique, which consists of an intradermal injection of 5 tuberculin units of PPD $(0.1 \mathrm{ml})$ into the volar surface of the forearm, using a 27 -gauge needle. The test should be read between 48 and 72 hours after the injection, measuring the transverse diameter of the induration. However, the interpretation of TST results is still controversial. The majority of the guidelines [1,9-11,23,28,31] affirms that TST should be considered positive if the diameter of the induration is $\geq 10 \mathrm{~mm}$ in any child and $\geq 5 \mathrm{~mm}$ in high risk children, including HIV-infected children and severely malnourished children. Otherwise the American guidelines $[12,14]$ recommend three different cut-points. Five millimetres should be considered positive in highrisk children, including close contact with contagious people with $\mathrm{TB}$, suspect of $\mathrm{TB}$ disease (i.e. chest radiograph suggestive of active or previous $\mathrm{TB}$ ) and immunodeficiency (i.e. HIV-infected children, children receiving immunosuppressive therapy). In children at increased risk of disseminated TB disease (i.e. children younger than 4 years, children with other medical conditions) and children with likelihood of being infected with M. tuberculosis (i.e. children born in high prevalence regions or children who travel to high prevalence regions) the cut-off proposed is $10 \mathrm{~mm}$. Eventually, TST $>15 \mathrm{~mm}$ is positive in children aged 4 years or older without any risk factors. All the guidelines agree that the TST result should be interpreted as positive regardless of Bacille Calmette-Guérin (BCG) vaccination, because there is no way of distinguishing between a positive TST due to $M$. tuberculosis infection and that caused by BCG vaccination.

Over the last decade new diagnostic tests have been developed for the detection of TB infection measuring, ex-vivo, the interferon-gamma released by $\mathrm{T}$-cells in response to mycobacterial antigens (IGRAs) [32]. QuantiFERON-TB Gold-In tube (Cellestis, Victoria, Australia) and T-SPOT.TB (Immunotec, Oxford, United Kingdom) have been approved by the United States Food and 
Table 1 National and international guidelines concerning paediatric tuberculosis.

\begin{tabular}{|c|c|c|c|c|c|}
\hline Guideline Title [Reference] & $\begin{array}{l}\text { Guideline } \\
\text { Developer(s) }\end{array}$ & $\begin{array}{l}\text { Countries or } \\
\text { Regions }\end{array}$ & Year & $\begin{array}{l}\text { Target } \\
\text { Population }\end{array}$ & $\begin{array}{l}\text { Guideline } \\
\text { Fields }\end{array}$ \\
\hline $\begin{array}{l}\text { Guidance for national tuberculosis programmes on the management of tuberculosis } \\
\text { in children [1] }\end{array}$ & $\mathrm{WHO}$ & International & 2006 & Children & $\begin{array}{l}\text { Diagnosis } \\
\text { Treatment }\end{array}$ \\
\hline Rapid advice. Treatment of tuberculosis in children [5] & $\mathrm{WHO}$ & International & 2010 & Children & Treatment \\
\hline $\begin{array}{l}\text { Use of tuberculosis interferon-gamma release assays (IGRAs) in low- and middle- } \\
\text { income countries: policy statement [6] }\end{array}$ & WHO & International & 2011 & $\begin{array}{l}\text { Adults } \\
\text { Children }\end{array}$ & Diagnosis \\
\hline $\begin{array}{l}\text { Policy statement: automated real-time nucleic acid amplification technology for } \\
\text { rapid and simultaneous detection of tuberculosis and rifampicin resistance: Xpert } \\
\text { MTB/RIF system [7] }\end{array}$ & $\mathrm{WHO}$ & International & 2011 & $\begin{array}{l}\text { Adults } \\
\text { Children }\end{array}$ & Diagnosis \\
\hline Guidelines for the programmatic management of drug-resistant tuberculosis [8] & $\mathrm{WHO}$ & International & 2011 & $\begin{array}{l}\text { Adults } \\
\text { Children }\end{array}$ & Treatment \\
\hline Desk-guide for diagnosis and management of TB in children [9] & IUATLD & International & 2010 & Children & $\begin{array}{l}\text { Diagnosis } \\
\text { Treatment }\end{array}$ \\
\hline Evaluation of Tuberculosis Diagnostics in Children $[10,11]$ & Expert Panel & International & 2012 & Children & Diagnosis \\
\hline Tuberculosis (in: Red Book 2012) [12] & AAP & U.S. & 2012 & Children & $\begin{array}{l}\text { Diagnosis } \\
\text { Treatment }\end{array}$ \\
\hline Treatment of Tuberculosis [13] & $\begin{array}{l}\text { ATS } \\
\text { CDC } \\
\text { IDSA }\end{array}$ & U.S. & 2003 & $\begin{array}{l}\text { Adults } \\
\text { Children }\end{array}$ & Treatment \\
\hline Diagnostic Standards and Classification of Tuberculosis in Adults and Children [14] & $\begin{array}{l}\text { ATS } \\
\text { CDC } \\
\text { IDSA }\end{array}$ & U.S. & 2000 & $\begin{array}{l}\text { Adults } \\
\text { Children }\end{array}$ & Diagnosis \\
\hline $\begin{array}{l}\text { Updated Guidelines for the Use of Nucleic Acid Amplification Tests in the Diagnosis } \\
\text { of Tuberculosis [15] }\end{array}$ & CDC & U.S. & 2009 & $\begin{array}{l}\text { Adults } \\
\text { Children }\end{array}$ & Diagnosis \\
\hline $\begin{array}{l}\text { Updated Guidelines for Using Interferon Gamma Release Assays to Detect } \\
\text { Mycobacterium tuberculosis Infection [16] }\end{array}$ & CDC & U.S. & 2010 & $\begin{array}{l}\text { Adults } \\
\text { Children }\end{array}$ & Diagnosis \\
\hline $\begin{array}{l}\text { Recommendations for Use of an Isoniazid-Rifapentine Regimen with Direct } \\
\text { Observation to Treat Latent Mycobacterium tuberculosis Infection [17] }\end{array}$ & $\mathrm{CDC}$ & U.S. & 2011 & $\begin{array}{l}\text { Adults } \\
\text { Children }\end{array}$ & Treatment \\
\hline European Union Standards for Tuberculosis Care [18] & $\begin{array}{l}\text { ECDC } \\
\text { ERS }\end{array}$ & Europe & 2012 & $\begin{array}{l}\text { Adults } \\
\text { Children }\end{array}$ & $\begin{array}{l}\text { Diagnosis } \\
\text { Treatment }\end{array}$ \\
\hline Use of interferon-gamma release assays in support of TB diagnosis [19] & ECDC & Europe & 2011 & $\begin{array}{l}\text { Adults } \\
\text { Children }\end{array}$ & Diagnosis \\
\hline Management of contacts of MDR TB and XDR TB patients [20] & ECDC & Europe & 2012 & $\begin{array}{l}\text { Adults } \\
\text { Children }\end{array}$ & $\begin{array}{l}\text { Diagnosis } \\
\text { Treatment }\end{array}$ \\
\hline $\begin{array}{l}\text { LTBI: latent tuberculosis infection or lasting immune responses to M. tuberculosis? A } \\
\text { TBNET consensus statement [21] }\end{array}$ & TBNET & Europe & 2009 & $\begin{array}{l}\text { Adults } \\
\text { Children }\end{array}$ & Diagnosis \\
\hline $\begin{array}{l}\text { Clinical diagnosis and management of tuberculosis, and measures for its prevention } \\
\text { and control [22] }\end{array}$ & NICE & U.K. & 2011 & $\begin{array}{l}\text { Adults } \\
\text { Children }\end{array}$ & $\begin{array}{l}\text { Diagnosis } \\
\text { Treatment }\end{array}$ \\
\hline $\begin{array}{l}\text { Diagnosis of tuberculosis in pediatrics. Consensus document of the Spanish Society } \\
\text { of Pediatric Infectology (SEIP) and the Spanish Society of Pediatric Pneumology } \\
\text { (SENP) [23] }\end{array}$ & $\begin{array}{l}\text { SEIP } \\
\text { SENP }\end{array}$ & Spain & 2010 & Children & Diagnosis \\
\hline Consensus document for the treatment of pulmonar tuberculosis in children [24] & SEIP & Spain & 2007 & Children & Treatment \\
\hline $\begin{array}{l}\text { Recommendations of the Spanish Society for Pediatric Infectious Diseases (SEIP) on } \\
\text { the management of drug-resistant tuberculosis [25] }\end{array}$ & SEIP & Spain & 2009 & Children & Treatment \\
\hline $\begin{array}{l}\text { Consensus document on treatment of tuberculosis exposure and latent tuberculosis } \\
\text { infection in children [26] }\end{array}$ & SEIP & Spain & 2006 & Children & Treatment \\
\hline $\begin{array}{l}\text { Recommendations for Therapy, Chemoprevention and Chemoprophylaxis of } \\
\text { Tuberculosis in Adults and Children [27] }\end{array}$ & $\begin{array}{l}\text { DZK } \\
\text { DGP }\end{array}$ & Germany & 2012 & $\begin{array}{l}\text { Adult } \\
\text { Children }\end{array}$ & Treatment \\
\hline $\begin{array}{l}\text { Childhood tuberculosis guidelines of the Southern African Society for Paediatric } \\
\text { Infectious Diseases [28] }\end{array}$ & SASPID & South Africa & 2009 & Children & $\begin{array}{l}\text { Diagnosis } \\
\text { Treatment }\end{array}$ \\
\hline Consensus Statement on Childhood Tuberculosis [29] & IAP & India & 2010 & Children & $\begin{array}{l}\text { Diagnosis } \\
\text { Treatment }\end{array}$ \\
\hline
\end{tabular}


Table 1 National and international guidelines concerning paediatric tuberculosis. (Continued)

\begin{tabular}{|c|c|c|c|c|c|}
\hline Management of tuberculosis in children [30] & $\begin{array}{l}\text { ASID } \\
\text { APRG }\end{array}$ & Australasia & 2000 & Children & Treatment \\
\hline Canadian Tuberculosis Standards $7^{\text {th }}$ Edition [31] & $\begin{array}{l}\text { PHAC } \\
\text { CTS } \\
\text { CLA }\end{array}$ & Canada & 2013 & $\begin{array}{l}\text { Adult } \\
\text { Children }\end{array}$ & $\begin{array}{l}\text { Diagnosis } \\
\text { Treatment }\end{array}$ \\
\hline
\end{tabular}

Note. WHO: World Health Organization; IUATLD: International Union Against Tuberculosis and Lung Disease; AAP: American Academy of Pediatrics; ATS: American Thoracic Society; CDC: Center for Control Disease and Prevention; IDSA: Infectious Diseases Society of America; ECDC: European Center for Disease Control and Prevention; ERS: European Respiratory Society; NICE: National Institute for Health and Care Excellence; SEIP: Spanish Society for Paediatric Infectious Diseases; SENP: Spanish Society for Paediatric Respiratory Disease; DZK: German Central Committee against Tuberculosis; DGP: German Respiratory Society; SASPID: Southern African Society for Paediatric Infectious Diseases; IAP: Indian Academy of Pediatrics; ASID: Australasian Society for Infectious Diseases (Subgroup of Paediatric Infectious Disease); APRG: Australasian Paediatric Respiratory Group; PHAC: Public Health Agency of Canada; CTS: Canadian Thoracic Society; CLA: Canadian Lung Association.

Drug Administration [19] and licensed for commercial distribution in Europe [16] and several other countries [28,29,31].

All the recent guidelines are in agreement that IGRAs represent a relevant diagnostic tools for the identification of $M$. tuberculosis infection, except for one [9] which do not discuss the role of IGRAs in the diagnosis of TB infection. The CDC, the ECDC and the WHO have published specific recommendations focusing on the use of IGRAs in TB and LTBI diagnosis $[6,16,19]$. They analyze the sensitivity and specificity of the test, the costs and the role of IGRAs in the diagnosis of TB infection both in adults and children. Whereas the guidelines developed in high-income settings discuss extensively the use of IGRAs [21-23,31], those from middle or low-income countries only mention IGRAs [28,29].

All guidelines underline that few data concerning the use of IGRAs in childhood are available, but the IGRAs seem to perform well in children aged 5 years or older. The sensitivity of IGRAs for detecting TB infection in childhood is generally similar to TST, according also to recent meta-analysis [32-34]. The IGRAs specificity seems to be higher than TST, because the antigens used are absent in most pathogenic non-tuberculous mycobacteria, as well as in BCG strains. This characteristic explains the IGRAs advantage over TST in identifying a natural $M$. tuberculosis infection in settings with high non-tuberculous mycobacteria exposure and high BCG vaccination coverage [21,35]. Moreover boosting does not occur when the test is repeated, being particularly useful in BCGvaccinated children. Anyway the IGRA tests have a reduced accuracy for the detection of $M$. tuberculosis infection in high-burden TB settings compared with lowburden TB settings [33,35]. Indeed IGRAs are unsuitable for resource-limited settings, being expensive and requiring sophisticated laboratory support and trained personal for accurate performance. According to that, the WHO [6] strongly recommends that IGRAs should not replace the TST for the detection of TB infection in children in low or middle-income countries, regardless of HIV status.
On the contrary, the NICE guidelines [22] encourage the use of IGRAs and suggest considering those for all children aged 5 years or older whose TST shows positive results. Differently, European [19], Spanish [23], Canadian [31] and American [12,16] guidelines affirm that the selection of the most suitable test or combination of tests should be based on clinical data, as BCG status, history of contact with active TB or other risk factors for infection or progression of the disease (table 2).

\section{Diagnostic tools for TB disease}

All guidelines [1,9-12,14,18,22,23,28,29,31] agree that the isolation of $M$. tuberculosis complex from different specimens as sputum (natural or induced), gastric aspirates, bronchial washings, pleural fluid, cerebrospinal fluid, urine or biopsy tissue is the gold standard for the diagnosis of TB. Older children and adolescents frequently can produce sputum spontaneously or by induction with aerosolized hypertonic saline. Otherwise early-morning gastric aspirate, collected on three separate days, represents an option for young children and any child in whom sputum cannot be obtained. All guidelines underline that a microbiological confirmation should always be sought using all the resources available, although is well known that children are generally paucibacillary.

The first bacteriological evidence of the presence of mycobacteria in a clinical specimen is the detection of acid fast bacilli (AFB) in stained smears examined microscopically. This test gives an estimation of the numbers of bacilli excreted and therefore of the patient's infectiousness. However, the results of AFB smears of gastric aspirates are often negative and also the presence of nontubercolous mycobacteria, can cause false-positive results $[12,31]$. For these reasons all clinical specimens should be inoculated into culture media. Despite culture is the gold standard for laboratory confirmation of TB disease, M. tuberculosis is isolated from less than $50 \%$ of children and $75 \%$ of infants with pulmonary tuberculosis $[12,31,36]$.

In low-income settings, where the facilities and resources are limited, bacteriological confirmation should 
Table 2 Recommendations for the use of Tuberculin Skill Test (TST) and Interferon-gamma Release Assay (IGRA) in children

\begin{tabular}{|c|c|c|c|}
\hline & TST alone & IGRA alone & both TST and IGRA \\
\hline WHO [6] & $\begin{array}{l}\text { - Any child, irrespective of HIV status, in low and } \\
\text { middle-income countries }\end{array}$ & & \\
\hline NICE [22] & - Children younger than 5 years & $\begin{array}{l}\text { - BCG vaccinated children (> } 5 \text { years of } \\
\text { age) } \\
\text { - Children }>5 \text { years of age, in an } \\
\text { outbreak situation }\end{array}$ & $\begin{array}{l}\text { - Children }>5 \text { years of age whose TST } \\
\text { is positive }\end{array}$ \\
\hline $\begin{array}{l}\text { American } \\
{[12,16]}\end{array}$ & $\begin{array}{l}\text { - Children younger than } 5 \text { years } \\
\text { - Before initiation of immunosuppressive therapy }\end{array}$ & $\begin{array}{l}\text { - BCG vaccinated children (> } 5 \text { years of } \\
\text { age) } \\
\text { - Children }>5 \text { years of age who are } \\
\text { unlikely to return for TST reading } \\
\text { - Before starting immunosuppressive } \\
\text { therapy }\end{array}$ & $\begin{array}{l}\text { - The initial and repeat IGRA are } \\
\text { indeterminate } \\
\text { - The initial test (TST or IGRA) is } \\
\text { negative and: } \\
\text { - clinical suspicion for TB disease is } \\
\text { moderate to high } \\
\text { - risk of progression and poor outcome } \\
\text { is high } \\
\text { - The initial TST is positive and: } \\
\text { - Children > } 5 \text { years of age who have } \\
\text { received BCG vaccine } \\
\text { - Non-tuberculous mycobacterial } \\
\text { disease is suspected } \\
\text { - Additional evidence are needed to } \\
\text { increase compliance }\end{array}$ \\
\hline $\begin{array}{l}\text { European } \\
{[19]}\end{array}$ & $\begin{array}{l}\text { - Children younger than } 5 \text { years } \\
\text { - Children > } 5 \text { years who are: } \\
\text { - not HIV-infected } \\
\text { - not BCG vaccinated }\end{array}$ & $\begin{array}{l}\text { - BCG vaccinated children (> } 5 \text { years of } \\
\text { age) }\end{array}$ & $\begin{array}{l}\text { - HIV-infected children } \\
\text { - Before starting immunosuppressive } \\
\text { therapy (anti-TNFalfa inhibitor therapy) }\end{array}$ \\
\hline $\begin{array}{l}\text { Spanish } \\
{[23]}\end{array}$ & - Any child & & $\begin{array}{l}\text { - The initial TST is negative and: } \\
\text { - Immunocompromised children } \\
\text { - High risk of infection, of progression } \\
\text { to disease and of a poor outcome } \\
\text { - The initial TST is positive and: } \\
\text { - BCG vaccinated children } \\
\text { - Risk factors are negative }\end{array}$ \\
\hline $\begin{array}{l}\text { Canadian } \\
{[31]}\end{array}$ & $\begin{array}{l}\text { - Whenever it is planned to repeat the test later } \\
\text { to assess risk of new infection (i.e. conversions) }\end{array}$ & $\begin{array}{l}\text { - People who have received BCG } \\
\text { vaccination } \\
\text { - People from groups that historically } \\
\text { have poor rates of return for TST reading. }\end{array}$ & $\begin{array}{l}\text { - High risk of infection, of progression } \\
\text { to disease and of a poor outcome } \\
\text { - The initial and repeat IGRA are } \\
\text { indeterminate }\end{array}$ \\
\hline
\end{tabular}

Note. WHO: World Health Organization; BCG: Bacille Calmette-Guèrin

be prioritized in children who have HIV infection, complicated or severe disease or suspected drug-resistant TB $[1,28]$. Moreover, the growth of the mycobacteria in culture is required not only for confirming the diagnosis and determining the mycobacteria species, but also for genotyping and drug susceptibility testing, according to all guidelines. Although all guidelines underline the importance of genotyping and drug susceptibility testing, only American and Spanish guidelines describe the methods used [14,23].

A relevant improvement in the direct identification of M. tuberculosis resulted from the introduction of nucleic acid amplification test (NAAT). The CDC [15] and the WHO [7] have recently published an updated guidelines for the use of NAAT in the diagnosis of TB in both children and adults, although some guidelines only explain briefly their potential implications [12,18,22,23,28,29,31], and other do not consider this topic [9-11]. The NAATs are rapid and accurate methods. They can provide the results within 24-48 hours, one or more weeks earlier than culture. Global sensitivity is greater than 95\% in AFBmicroscopy positive respiratory specimens and ranges between $50-80 \%$ in AFB-smear negative specimens [15]. Currently several assays are available, including line probe assays (LPAs) and NAATs using polymerase chain reaction (PCR). Real-time PCR is becoming increasingly available and several guidelines purpose its use for $M$. tuberculosis detection in respiratory specimens [7,12-15,18,22,23,28,31]. The CDC [15] recommends the use of NAAT in any patient with signs and symptoms of pulmonary $\mathrm{TB}$, for whom a diagnosis has not yet been established or for whom the test result would change the case management. The NICE guideline [22], on the contrary, limits NAAT use only to sputum smear positive persons for whom the rapid confirmation of TB diagnosis would change their care. Other guidelines [23,28,31] underline the useful of NAAT, but they do not provide specific indications. However, all guidelines agree that 
NAATs do not replace AFB smear and culture, which should be always performed. Moreover the NAATs should not be used for treatment monitoring as they persist positive for long periods after therapy, being unable to distinguish live from dead bacilli.

However, evidence concerning NAATs accuracy for nonrespiratory specimens are limited. Further research is needed before NAATs can be recommended for the diagnosis of TB in children who cannot produce sputum [12,15].

The NAATs are also able to detect drug resistance. If the AFB-smear is negative, as it frequently occurs in children, the NAAT of choice is the Xpert-MTB/RIF (Cepheid, Sunnyvale, California, USA) which is a real-time PCR assay detecting the 81-bp-core region of the RNApolymerase b-subunit gene. This region, which is closed to M. tuberculosis specific DNA sequences, accounts for more than $95 \%$ of rifampicin (RIF) resistance. Therefore the Xpert-MTB/RIF can be used for the detection of RIF-resistance [37,38]. Additionally, given that rifampicin resistance is usually accompanied by isoniazid resistance, it can be used also as a rapid marker of multi-drug resis$\operatorname{tant}$ (MDR) TB. According to these findings, the WHO $[7,8]$ recommends the Xpert-MTB/RIF as the initial diagnostic test in children and adolescents suspected of having multidrug-resistant (MDR)-TB or HIV-associated TB. The WHO also suggests to consider it as a follow-on test to microscopy in settings where MDR-TB or HIV are of lesser concern, especially in further testing of smear-negative specimens. The ECDC guidelines [18] confirm the WHO recommendations.

Among radiological tools, all guidelines $[1,9-12,18$, $22,23,28,29,31]$ are in agreement that chest radiography is an important part of the diagnostic workup of TB and should be performed in any child with suspected TB. Chest radiographic features vary widely, showing normal findings as well as lymphadenopathy, atelectasis, cavitary lesions, miliary disease and pleural effusion. There are no pathognomonic radiological sings of $\mathrm{TB}$, but some radiological lesions strongly suggest TB, as miliary disease, hilar and paratracheal lymphadenopathy or cavitary lesions.

A general consensus exists also concerning the use of chest $\mathrm{CT}$ only for complicated cases, considering the high level of radiation exposure and the high costs related to its use.

The CT, as well as magnetic resonance, may also be very helpful in the evaluation of TB meningitis, osteoarticular disease, intra or extra-thoracic lymphadenopathy and pericardial TB.

\section{Treatment for TB disease}

The major goals of anti-TB treatment are to cure the patient by eliminating most of the bacilli, prevent the development of drug resistance by using a drug combination regimen, prevent $\mathrm{TB}$ relapse by eliminating the quiescent bacilli and, finally, decrease the TB transmission to others.

The poor adherence to the anti-TB therapy represents the main contributory factor to treatment failure and emergence of TB drug-resistance. In order to improve the compliance to the treatment, all guidelines $[1,5,9,12$, $13,18,22,24,25,27-31]$ emphasize the widespread use of the directly observed therapy (DOT), a patient-centred strategy in which patients are observed to ingest each dose of anti-TB drugs.

All guidelines are also in agreement that TB treatment should include an initial intensive phase, when three to four drugs are used in order to kill the majority of bacilli and prevent the emergence of drug resistance, and a continuation phase, when fewer drugs are given in order to eradicate quiescent bacilli. The firstline anti-TB drugs, their dosages and adverse events are summarized in table 3 . The guidelines considered in the present review recommend the same standard treatment regimen for pulmonary $\mathrm{TB}$ (table 4). Children living in settings were HIV prevalence is high or isoniazid (INH)-resistance is high, or both, should be treated with a four drugs regimen (INH, RIF, pyrazinamide-PZA and ethambutol-EMB) for 2 months, followed by a two drugs regimen (INH, RIF) for 4 months. However, if the risk of drug-resistance and the HIV prevalence are low, EMB can be omitted, considering that it can cause retrobulbar neuritis and could be difficultly monitoring in children. Despite two recent systematic reviews $[39,40]$ show that an

Table 3 First-line drugs used for treatment of tuberculosis in childhood [1,9,12,13,24,27-31]

\begin{tabular}{llll}
\hline & $\begin{array}{l}\text { Daily dosage } \\
\text { (maximum dosage) }\end{array}$ & $\begin{array}{l}\text { Twice-thrice weekly dosage } \\
\text { (maximum dosage) }\end{array}$ & Adverse Reactions \\
\hline $\begin{array}{l}\text { Isoniazid } \\
\text { (INH) }\end{array}$ & $\begin{array}{l}10-15 \mathrm{mg} / \mathrm{kg} \\
(300 \mathrm{mg})\end{array}$ & $\begin{array}{l}20-30 \mathrm{mg} / \mathrm{kg} \\
(900 \mathrm{mg})\end{array}$ & $\begin{array}{l}\text { Hepatotoxic effects, such as mild hepatic enzyme elevation and hepatitis, } \\
\text { gastritis, peripheral neuropathy, hypersensitivity }\end{array}$ \\
\hline $\begin{array}{l}\text { Rifampicin } \\
\text { (RIF) }\end{array}$ & $\begin{array}{l}10-20 \mathrm{mg} / \mathrm{kg} \\
(600 \mathrm{mg})\end{array}$ & $\begin{array}{l}10-20 \mathrm{mg} / \mathrm{kg} \\
(600 \mathrm{mg})\end{array}$ & $\begin{array}{l}\text { Orange discoloration of secretions and urine, vomiting, hepatitis, influenza- } \\
\text { like reaction, thrombocytopenia }\end{array}$ \\
\hline $\begin{array}{l}\text { Pyrazinemide } \\
\text { (PZA) }\end{array}$ & $\begin{array}{l}30-40 \mathrm{mg} / \mathrm{kg} \\
(2 \mathrm{~g})\end{array}$ & $\begin{array}{l}50 \mathrm{mg} / \mathrm{kg} \\
(2 \mathrm{~g})\end{array}$ & $\begin{array}{l}\text { Hepatotoxic effects, hyperuricemia, arthralgia, gastrointestinal tract } \\
\text { disturbances }\end{array}$ \\
\hline $\begin{array}{l}\text { Ethambutol } \\
\text { (EMB) }\end{array}$ & $15-25 \mathrm{mg} / \mathrm{kg}$ & $\begin{array}{l}50 \mathrm{mg} / \mathrm{kg} \\
(2,5 \mathrm{~g})\end{array}$ & $\begin{array}{l}\text { Optic neuritis with decreased red-green colour discrimination and visual } \\
\text { acuity, gastrointestinal disturbances, hypersensitivity }\end{array}$ \\
\hline
\end{tabular}


Table 4 Recommendations for treatment of TB in childhood $[1,8,9,12,13,17,18,21,22,24,27-31]$

\begin{tabular}{|c|c|c|}
\hline & $\begin{array}{l}\text { Intensive phase } \\
\text { (duration) }\end{array}$ & $\begin{array}{l}\text { Continuation phase } \\
\text { (duration) }\end{array}$ \\
\hline $\begin{array}{l}\text { TB disease (except meningitis and osteoarticular TB) in HIV-uninfected children with } \\
\text { low risk of INH-resistance }\end{array}$ & $\begin{array}{l}\text { INH + RIF + PZA ( } 2 \\
\text { months) }\end{array}$ & INH + RIF (4 months) \\
\hline $\begin{array}{l}\text { TB disease (except meningitis and osteoarticular TB) in HIV-infected children and/or } \\
\text { children with high risk of INH-resistance }\end{array}$ & $\begin{array}{l}\text { INH + RIF + PZA + EMB } \\
\text { (2 months) }\end{array}$ & INH + RIF (4 months) \\
\hline Meningitis and osteoarticular TB & $\begin{array}{l}\text { INH + RIF + PZA + EMB } \\
\text { (2 months) }\end{array}$ & INH + RIF (10 months) \\
\hline \multirow[t]{3}{*}{ INH-monoresistance TB } & $\begin{array}{l}\text { RIF + PZA + EMB (2 } \\
\text { months })^{\S}\end{array}$ & $\begin{array}{l}\text { RIF + PZA + EMB (4-7 } \\
\text { months) }\end{array}$ \\
\hline & $\begin{array}{l}\mathrm{RIF}+\mathrm{PZA}+\mathrm{EMB}(2 \\
\text { months) }\end{array}$ & $\mathrm{RIF}+\mathrm{EMB}$ (10 months) \# \\
\hline & $\begin{array}{l}\mathrm{RIF}+\mathrm{PZA}+\mathrm{EMB}+\mathrm{FQN} \\
(2 \text { months })\end{array}$ & $\begin{array}{l}\text { RIF + EMB + FQN (4-7 } \\
\text { months) } \#\end{array}$ \\
\hline \multirow[t]{2}{*}{ RIF-monoresistance TB } & $\begin{array}{l}\text { INH+ PZA + EMB + FQN } \\
(2 \text { months })^{\S}\end{array}$ & $\begin{array}{l}\text { INH + EMB + FQN (10- } \\
16 \text { months) }\end{array}$ \\
\hline & $\begin{array}{l}\mathrm{INH}+\mathrm{PZA}+\mathrm{EMB}(2 \\
\text { months) }\end{array}$ & $\underset{\#}{\mathrm{INH}}+\mathrm{EMB}(16$ months $)$ \\
\hline MDR-resistance TB & \multicolumn{2}{|c|}{$\begin{array}{l}\text { Treatment regimens should be based on the drug } \\
\text { susceptibility pattern of the } M \text {. tuberculosis isolated } \\
\text { from child specimens or, more frequently, from the } \\
\text { source case specimens. }\end{array}$} \\
\hline \multirow[t]{3}{*}{ LTBI } & \multicolumn{2}{|l|}{$\mathrm{INH}$ (6-9 months) ${ }^{\S}$} \\
\hline & \multicolumn{2}{|l|}{$\overline{\mathrm{INH}}+\mathrm{RIF}$ (3 months) ${ }^{\#}$} \\
\hline & \multicolumn{2}{|c|}{$\mathrm{INH}+\mathrm{RPT}$ (weekly for 12 weeks) ${ }^{\#}$} \\
\hline INH-monoresistance LTBI & \multicolumn{2}{|l|}{ RIF (4-6 months) } \\
\hline
\end{tabular}

Note: § recommended regimen; \# alternative regimen; TB: Tuberculosis; INH: Isoniazid; RIF: Rifampicin; PZA: Pyrazinamide; EMB: Ethambutol; FQN: Fluoroquinolones; MDR: Multi- Drug Resistance; RPT: Rifabutin.

intermittent short course of therapy is less likely to cure tuberculosis in childhood compare to daily therapy, several guidelines $[1,5,9,12,13,22,24,27,30,31]$ purpose both daily and intermittent (twice or thrice weekly) dosing regimens, and major discrepancies are evidenced. The AAP [12], the ATS along with the CDC [13], as well as the APRG along with ASID [30] recommend a daily or twice-weekly regimen in both intensive and continuation phases. The NICE [22], otherwise, excludes the use of twice-weekly regimen for the treatment of active TB, suggesting a thrice-weekly intermittent regimens only for patients receiving DOT. The WHO [1], the IUATLD [9] and the CTS [31] limit a thrice-weekly regimen to children known to be HIV uninfected and living in settings with well established DOT, and they allow an intermittent regimen only during the continuation phase. Finally Spanish guidelines [24] agree that children who are known to be reliable with DOT may be considered for both twice and thrice-weekly regimens.

A general consensus exists concerning treatment regimes for extra-pulmonary TB (table 4): except for meningitis and osteoarticular $\mathrm{TB}$, the standard recommended regimen $(\mathrm{INH}+\mathrm{RIF}+\mathrm{PZA}+\mathrm{EMB}$ for 2 months, followed by INH + RIF for 4 months) should be started.
Otherwise, the guidelines strongly recommend 12 months of therapy for meningeal TB $[1,5,9,12,13,22,27,30,31]$ and osteoarticular TB [1,5,9,22,27,30,31].

Among drug-resistance $\mathrm{TB}$, only few guidelines $[1,8,12,25,30,31]$ provide specific recommendations, probably due to the lack of evidence concerning this issue in childhood. Recommended regimens [8,12,25,30,31] for INH-monoresistance and RIF-monoresistance TB are listed in table 4. Despite the evidence concerning safety and efficacy in TB treatment of fluoroquinolones in children are few, all guidelines recommend their introduction in the treatment of monodrug-resistance TB, considering the indirect evidence from cystic fibrosis and osteomyelitis treatment in children.

The AAP [12] define the MDR as a TB infection or disease caused by a strain of $M$. tuberculosis complex that is resistant to at least INH and RIF. For MDR-TB cases, all guidelines $[1,8,18,12,25,30,31]$ are in agreement that the treatment should be based on the drug susceptibility pattern of the M. tuberculosis isolated from child specimens or, more frequently, from the source case specimens. All guidelines also affirm that treatment regimen should include at least four anti-TB drugs to which the organism isolated is susceptible $[1,8,18,12,25,31]$, except for Australasian one that recommends the use of at least two drugs 
Table 5 Second-line drugs used for TB treatment in children [8,12,13,25,27,30,31]

\begin{tabular}{|c|c|c|}
\hline & Daily dosage (maximum dosage) & Adverse Reactions \\
\hline Streptomycin & $\begin{array}{l}20-40 \mathrm{mg} / \mathrm{kg} \\
(1 \mathrm{~g})\end{array}$ & Auditory, vestibular and renal toxicity, rash \\
\hline $\begin{array}{l}\text { Amikacin } \\
\text { Kanamycin } \\
\text { Capreomycin }\end{array}$ & $\begin{array}{l}15-30 \mathrm{mg} / \mathrm{kg} \\
(1 \mathrm{~g})\end{array}$ & Auditory, vestibular and renal toxicity \\
\hline Ethionamide & $\begin{array}{l}15-20 \mathrm{mg} / \mathrm{kg} / \mathrm{die} \text {, given in } 2-3 \text { divided } \\
\text { doses } \\
(1 \mathrm{~g})\end{array}$ & $\begin{array}{l}\text { Hepatotoxic effects, gastrointestinal tract disturbances, neurotoxicity, hypersensitivity } \\
\text { and hypothyroid }\end{array}$ \\
\hline $\begin{array}{l}\text { Para-amino salicylic } \\
\text { acid }\end{array}$ & $\begin{array}{l}200-300 \mathrm{mg} / \mathrm{kg} / \mathrm{die} \text {, given in } 2-4 \\
\text { divided doses } \\
(10 \mathrm{~g})\end{array}$ & Hepatotoxic effects, gastrointestinal tract disturbances, hypersensitivity \\
\hline Cycloserine & $\begin{array}{l}\text { 10-20 mg/kg, given in 2-divided doses } \\
(1 \mathrm{~g})\end{array}$ & Psychosis, personality changes, seizure, rash \\
\hline Moxifloxacin & $\begin{array}{l}10 \mathrm{mg} / \mathrm{kg} \\
(400 \mathrm{mg})\end{array}$ & $\begin{array}{l}\text { Theoretical effect on growing cartilage, gastrointestinal tract disturbances, rash, } \\
\text { headache, restlessness }\end{array}$ \\
\hline Levofloxacin & $\begin{array}{l}10 \mathrm{mg} / \mathrm{kg} \\
(1 \mathrm{~g})\end{array}$ & \\
\hline Linezolid & $\begin{array}{l}10 \mathrm{mg} / \mathrm{kg} \\
(1,2 \mathrm{~g})\end{array}$ & gastrointestinal tract disturbances, peripheral neuropathy, thrombocytopenia \\
\hline
\end{tabular}

certain to be effective [30]. Additionally treatment duration should be prolonged and ranges from 12 to 24 months in the different guidelines $[1,8,18,12,25,30,31]$. Second-line drugs used in paediatric TB are listed in table 5 .

\section{Treatment for LTBI}

After exposure to an active case, children are more likely to develop tuberculosis than adults, hence contact screening and chemoprophylaxis are particularly important. Several guidelines discuss LTBI and its treatment $[1,12,13,17,18,21,26-31]$ and all of those are in agreement that any child who has an history of TB exposure, positivity of TST and/or IGRA, but not evidence of active tuberculosis, should start the treatment for LTBI (table 4).

Isoniazid represents the preferred drug for children with LTBI, unless INH-resistance is suspected, and the efficacy approaches about $100 \%$ if the adherence to therapy is adequate [12]. All guidelines [1,12,13,17,18,21,26-31] suggest using isoniazid alone for LTBI treatment in childhood although minor differences concern the treatment duration, which ranges from 6 months $[1,22,26,28-30]$ to 9 months $[12,13,17,21,27,31]$. Additionally the NICE [22] and the Southern African [28] guidelines purpose 3 months of INH and RIF as alternative therapy regimen. Recently the CDC has published recommendations for the use of a new combination regimen of rifapentin (RPT) and INH to be administered weekly for 12 weeks as DOT [17]. Although the evidence on tolerability and efficacy of this combination in childhood is lacking, it can be considered in selected cases, if the compliance to treatment is low and the hazard of TB is high.
Rifampicin alone for 4-6 months is recommended for the treatment of LTBI if a resistance to INH is strongly suspected or demonstrated $[1,12,13,21,26,27,30,31]$. However, on the basis of the currently available evidences, second-line drugs are not recommended for the chemoprophylaxis in MDR-TB contacts.

\section{Conclusions}

The present systematic review has identified 27 national and international guidelines concerning the management of paediatric tuberculosis [1,5-31].

There are several discrepancies on the diagnosis workup of TB. Major differences concern the TST interpretation. Most of the guidelines [1,9-11,23,28,31] establish a cutpoint of $10 \mathrm{~mm}$ for any child and $5 \mathrm{~mm}$ for high risk children, although the American guidelines [12,14] increase the cut-point to $15 \mathrm{~mm}$ for children without any risk factors and to $10 \mathrm{~mm}$ for children with minor risk factors, maintaining the diameter of $5 \mathrm{~mm}$ only for high risk population. Considering that TST sensitivity and specificity are influenced by the cut-off used [21], differences among guidelines are not merely academic but have important consequences for clinical practice. Recommendations also differ substantially regarding the use of TST and IGRA for the diagnosis of TB infection. The guidelines from high-income countries $[12,16,22,23,19,31]$ widely promotes the IGRA use, whereas the WHO [6] strongly recommends that IGRAs should not replace the TST for the detection of TB infection in children in low or middle-income countries. These findings could be explained considering that IGRA has a reduced accuracy in high-burden TB settings compared with low-burden TB 
settings [33,35], is expensive and requires sophisticated laboratory support and trained personal $[6,16,21]$.

A general consensus exists, on the contrary, on the microbiological confirmation of TB diagnosis, despite in low-income settings the mycobacterial culture is not performed routinely and is limited to HIV-infected children or severe disease. Although all guidelines underline the importance of susceptibility drug testing and genotyping, the guidelines from low-income countries do not strongly recommend these tests routinely to all patients, probably because of costs and lack of facilities. Finally the use of NAATs for the direct detection of M. tuberculosis is still controversial. Whereas the CDC [15] and the WHO [7] have recently published an updated guidelines focusing on the use of NAATs, the majority of guidelines $[12,18,23,28,29,31]$ do not provide specific recommendations on their use. Moreover, evidence concerning NAATs accuracy for non-respiratory specimens are limited and further research is needed before NAATs can be recommended for the diagnosis of TB in children who cannot produce sputum $[12,15]$.

Despite advances in TB diagnostic tool have been reached over the last decade, a lack of uniformity in their availability, indication and interpretation has relevant consequences for clinical practice. Further research is needed to identify a reliable and reproducible diagnostic workup not only to improve individual case management, but also to provide a valid basis for epidemiological data analysis, drug efficacy evaluation and improving clinical trials.

The recommendations on TB treatment are otherwise homogeneous and only minor discrepancies are evidenced in the present review. The main point of disagreement is represented by the daily and intermittent (twice or thrice weekly) regimens recommended, which vary widely between different guidelines. The lack of evidence among the drugs metabolism and the efficacy of intermittent treatment regimes in childhood is probably the main reason of this finding. Further studies need to be performed in order to clarify this issue. Finally, the poor adherence to the therapy, which is often too long, represents a relevant concern, especially in low-income settings where DOT is not always guarantied. The combination regimen of RPT and INH, recently proposed by the CDC for LTBI, could be a valid alternative in these patients. Data on efficacy and safety of this combination are needed before address new recommendations. Moreover, new treatment regimens, indicated also for active TB, should be analyzed in future studies in order to improve the treatment compliance.

\section{Funding}

Italian Health Ministry / Young Research Project has provided the funding for publication of the present systematic review.

\section{List of abbreviations used}

AAP: American Academy of Pediatrics; AFB: Acid Fast Bacilli; APRG: Australasian Paediatric Respiratory Group; ASID: Australasian Society for Infectious Diseases; ATS: American Thoracic Society; BCG: Bacille Calmette-Guérin; CDC: Center for Disease Control and Prevention; CLA: Canadian Lung Association; CTS: Canadian Thoracic Society; DGP: German Respiratory Society; DOT: Directly Observed Therapy; DZK: German Central Committee against Tuberculosis; ECDC:

European Center for Disease Control and Prevention; EMB: Ethambutol ; ERS: European Respiratory Society; FQN: Fluoroquinolones; IAP: Indian Academy of Pediatrics; IDSA: Infectious Diseases Society of America; IGRA: Interferon-gamma Release Assays; IHN: Isoniazid; IUATLD: International Union Against Tuberculosis and Lung Disease; LPAs: Line Probe Assays; LTBI: Latent Tuberculosis Infection; MDR: Multi Drug Resistance; NAAT: Nucleic Acid Amplification Test; NICE: National Institute for Health and Care Excellence; PCR: Polymerase Chain Reaction; PHAC: Public Health Agency of Canada; PPD: Purified Protein Derivate, Tuberculin; PZA: Pyrazinamide; RIF: Rifampicin; RPT: Rifabutin; SASPID: Southern African Society for Paediatric Infectious Diseases; SEIP: Spanish Society for Paediatric Infectious Diseases; SENP: Spanish Society for Paediatric Respiratory Disease; TB: Tuberculosis; TST: Tuberculin Skin Test; WHO: World Health Organization

\section{Competing interests}

The authors declare that they have no competing interests.

\section{Declarations}

This article has been published as part of BMC Infectious Diseases Volume 14 Supplement 1, 2014: Highlights in Pediatric Tuberculosis. The full contents of the supplement are available online at http://www.biomedcentral.com/ bmcinfectdis/supplements/14/S1

Published: 8 January 2014

\section{References}

1. Stop TB Partnership Childhood TB Subgroup, World Health Organization: Guidance for National Tuberculosis Programmes on the management of tuberculosis in children. World Health Organization, Geneva 2006 [http:// whqlibdoc.who.int/hq/2006/WHO_HTM_TB_2006.371_eng.pdf].

2. World Health Organization: The Stop TB Strategy: building on and enhancing DOTS to meet the TB-related Millenium Development Goals. World Health Organization, Geneva 2006 [http://www.who.int/tb/ publications/2006/stop_tb_strategy.pdf].

3. World Health Organization: A research agenda for childhood tuberculosis. World Health Organization, Geneva 2007 [http://whqlibdoc.who.int/hq/2007/ WHO_HTM_TB_2007.381_eng.pdf].

4. World Health Organization: Report of the meeting on TB medicines for children- July 2008. World Health Organization, Geneva 2008 [http://www. stoptb.org/wg/dots_expansion/childhoodtb/assets/documents/Final\% 20report.pdf].

5. World Health Organization: Rapid advice. Treatment of tuberculosis in children. World Health Organization, Geneva 2010 [http://whqlibdoc.who.int/ publications/2010/9789241500449_eng.pdf].

6. World Health Organization: Use of tuberculosis interferon-gamma release assays (IGRAs) in low- and middle-income countries: policy statement. World Health Organization, Geneva 2011 [http://whqlibdoc.who.int/ publications/2011/9789241502672_eng.pdf].

7. World Health Organization: Policy statement: automated real-time nucleic acid amplification technology for rapid and simultaneous detection of tuberculosis and rifampicin resistance: Xpert MTB/RIF system. World Health Organizatio, Geneva 2011 [http://whqlibdoc.who.int/publications/ 2011/9789241501545_eng.pdf].

8. World Health Organization: Guidelines for the programmatic management of drug-resistant tuberculosis. World Health Organizatio, Geneva 2011 [http://whqlibdoc.who.int/publications/2011/ 9789241501583_eng.pdf].

9. International Union Against Tuberculosis and Lung Disease: Desk-guide for diagnosis and management of TB in children. International Union Against Tuberculosis and Lung Disease, Paris 2010 [http://www.theunion.org/index. php/en/resources/technical-publications/item/193-desk-guide-for-diagnosisand-management-of-tb-in-children-].

10. Graham SM, Ahmed T, Amanullah F, Browning R, Cardenas V, Casenghi M, Cuevas LE, Gale M, Gie RP, Grzemska M, Handelsman E, Hatherill M, 
Hesseling AC, Jean-Philippe P, Kampmann B, Kabra SK, Lienhardt C, LighterFisher J, Madhi S, Makhene M, Marais BJ, McNeeley DF, Menzies H, Mitchell C, Modi S, Mofenson L, Musoke P, Nachman S, Powell C, Rigaud M, Rouzier $V$, et al: Evaluation of tuberculosis diagnostics in children: 1. Proposed clinical case definitions for classification of intrathoracic tuberculosis disease. Consensus from an expert panel. J Infect Dis 2012, 205(Suppl 2):199-208.

11. Cuevas LE, Browning R, Bossuyt P, Casenghi M, Cotton MF, Cruz AT, Dodd LE, Drobniewski F, Gale M, Graham SM, Grzemska M, Heinrich N, Hesseling AC, Huebner R, Jean-Philippe P, Kabra SK, Kampmann B, Lewinsohn D, Li M, Lienhardt C, Mandalakas AM, Marais BJ, Menzies HJ, Montepiedra G, Mwansambo C, Oberhelman R, Palumbo P, Russek-Cohen E, Shapiro DE, Smith B, Soto-Castellares G, et al: Evaluation of tuberculosis diagnostics in children: 2. Methodological issues for conducting and reporting research evaluations of tuberculosis diagnostics for intrathoracic tuberculosis in children. Consensus from an expert panel. J Infect Dis 2012, 205(Suppl 2):209-215.

12. American Academy of Pediatrics: Tuberculosis. In Red book: 2012 Report of the Committee on Infectious Diseases. 29 edition. Elk Grove Village, Illinois, USA: American Academy of Pediatrics;Pickering LK 2012:736-759.

13. Centers for Disease Control and Prevention, American Thoracic Society and Infectious Diseases Society of America: Treatment of Tuberculosis. MMWR 2003, 52(RR-11):1-77.

14. Centers for Disease Control and Prevention, American Thoracic Society and Infectious Diseases Society of America: Diagnostic Standards and Classification of Tuberculosis in Adults and Children. Am J Respir Crit Care Med 2000, 161:1376-1395.

15. Centers for Disease Control and Prevention: Updated Guidelines for the Use of Nucleic Acid Amplification Tests in the Diagnosis of Tuberculosis. MMWR 2009, 58:7-10

16. Centers for Disease Control and Prevention: Updated Guidelines for Using Interferon Gamma Release Assays to Detect Mycobacterium tuberculosis Infection. MMWR 2010, 59(RR 5):1-25.

17. Centers for Disease Control and Prevention: Recommendations for Use of an Isoniazid-Rifapentine Regimen with Direct Observation to Treat Latent Mycobacterium tuberculosis Infection. MMWR 2011, 60:1650-1653.

18. European Centers for Disease Control and Prevention, European Respiratory Society: European Union Standards for Tuberculosis Care. Eur Respir J 2012, 39:807-819.

19. European Centers for Disease Control and Prevention: Use of interferongamma release assays in support of TB diagnosis. European Centers for Disease Control and Prevention, Stockholm 2011 [http://ecdc.europa.eu/en/ publications/publications/1103_gui_igra.pdf].

20. European Centers for Disease Control and Prevention: Management of contacts of MDR TB and XDR TB patients. European Centers for Disease Control and Prevention, Stockholm 2012 [http://www.ecdc.europa.eu/en/ publications/publications/201203-guidance-mdr-tb-contacts.pdf].

21. Mack U, Migliori GB, Sester M, Rieder HL, Ehlers S, Goletti D, Bossink A, Magdorf K, Hölscher C, Kampmann B, Arend SM, Detjen A, Bothamley G, Zellweger JP, Milburn H, Diel R, Ravn P, Cobelens F, Cardona PJ, Kan B, Solovic I, Duarte R, Cirillo DM, Lange C, TBNET: LTBI: latent tuberculosis infection or lasting immune responses to M. tuberculosis? A TBNET consensus statement. Eur Respir J 2009, 33:956-973.

22. National Institute for Health and Care Excellence: Clinical diagnosis and management of tuberculosis, and measures for its prevention and control. National Institute for Health and Care Excellence, Manchester 2011 [http://www.nice.org.uk/nicemedia/live/13422/53642/53642.pdf].

23. Moreno-Pérez $D$, Andrés Martín A, Altet Gómez N, Baquero-Artigao F, Escribano Montaner A, Gómez-Pastrana Durán D, González Montero R, Mellado Peña MJ, Rodrigo-Gonzalo-de-Liria C, Ruiz Serrano MJ, Sociedad Española de Infectología Pediátrica, Sociedad Española de Neumología Pediátrica: Diagnosis of tuberculosis in pediatrics. Consensus document of the Spanish Society of Pediatric Infectology (SEIP) and the Spanish Society of Pediatric Pneumology (SENP). An Pediatr 2010, 73:143.1-143.14.

24. Grupo de trabajo de Tuberculosis de la Sociedad Española de Infectología Pediátrica: Consensus document for the treatment of pulmonar tuberculosis in children. An Pediatr 2007, 66:597-602.

25. Mellado Peña MJ, Baquero-Artigao F, Moreno-Perez D, Grupo de trabajo de Tuberculosis de la Sociedad Española de Infectología Pediátrica: Recommendations of the Spanish Society for Pediatric Infectious
Diseases (SEIP) on the management of drug-resistant tuberculosis. An Pediatr 2009, 71:447-458.

26. Grupo de trabajo de Tuberculosis de la Sociedad Española de Infectología Pediátrica: Consensus Document on treatment of tuberculosis exposure and latent tuberculosis infection in children. An Pediatr 2006, 64:59-65.

27. Schaberg T, Bauer T, Castell S, Dalhoff K, Detjen A, Diel R, Greinert U, Hauer B, Lange C, Magdorf K, Loddenkemper R: Recommendations for Therapy, Chemoprevention and Chemoprophylaxis of Tuberculosis in Adults and Children. German Central Committee against Tuberculosis (DZK) and German Respiratory Society (DGP). Pneumologie 2012, 66:133-171.

28. Moore DP, Schaaf HS, Nuttall J, Marais BJ, the Southern African Society for Paediatric Infectious Diseases: Childhood tuberculosis guidelines of the Southern African Society for Paediatric Infectious Diseases. South Afr J Epidemiol Infect 2009, 24:57-68.

29. Working Group on Tuberculosis, Indian Academy of Pediatrics (IAP): Consensus Statement on Childhood Tuberculosis. Indian Pediatr 2010, 47:41-55.

30. Voss LM, Australasian Subgroup in Paediatric Infectious Disease of the Australasian Society for Infectious Diseases, Australasian Paediatric Respiratory Group: Management of tuberculosis in children. $J$ Paediatr Child Health 2000, 36:530-6.

31. Canadian Thoracic Society, Canadian Lung Association and Public Health Agency of Canada: Canadian Tuberculosis Standards., 72013 [http://www. respiratoryguidelines.ca/tb-standards-2013]

32. Montenegro SH, Gilman RH, Sheen P, Cama R, Caviedes L, Hopper T, Chambers R, Oberhelman RA: Improved detection of Mycobacterium tuberculosis in Peruvian children by use of a heminested IS6110 polymerase chain reaction assay. Clin Infect Dis 2003, 36:16-23.

33. Machingaidze S, Wiysonge CS, Gonzalez-Angulo Y, Hatherill M, Moyo S, Hanekom W, Mahomed $\mathrm{H}$ : The utility of an interferon gamma release assay for diagnosis of latent tuberculosis infection and disease in children: a systematic review and meta-analysis. Pediatr Infect Dis J 2011, 30:694-700.

34. Mandalakas AM, Detjen AK, Hesseling AC, Benedetti A, Menzies D: Interferon-gamma release assays and childhood tuberculosis: systematic review and meta-analysis. Int J Tuberc Lung Dis 2011, 15:1018-1032.

35. Detjen AK, Keils T, Roll S, Mauch H, Wahn U, Magdorf K: Interferon- $\gamma$ release assays improve the diagnosis of tuberculosis and nontuberculous mycobacterial disease in children in a country with a low incidence of tuberculosis. Clin Infec Dis 2007, 45:322-328.

36. Stockdale AJ, Duke T, Graham S, Kelly J: Evidence behind the WHO guidelines: hospital care for children: What is the diagnostic accuracy of gastric aspiration for the diagnosis of tuberculosis in children? I Trop Pediatr 2010, 56:291-298.

37. Lawn SD, Nicol MP: Xpert1 MTB/RIF assay: development, evaluation and implementation of a new rapid molecular diagnostic for tuberculosis and rifampicin resistance. Future Microbiol 2011, 6:1067-1082.

38. Cordova J, Shiloh R, Gilman RH, Sheen P, Martin L, Arenas F, Caviedes L, Kawai V, Soto G, Williams DL, Zimic M, Escombe AR, Evans CA: Evaluation of molecular tools for detection and drug susceptibility testing of Mycobacterium tuberculosis in stool specimens from patients with pulmonary tuberculosis. J Clin Microbiol 2010, 48:1820-1826.

39. Ridge A, Whyte P, Grzemska M, Donald P, Hill S: Beyond randomized trials - TB treatment in children. Evid -Based Child Health 2010, 5:1566-1577.

40. Menon PR, Lodha R, Sivanandan S, Kabra SK: Intermittent or daily short course chemotherapy for tuberculosis in children: meta-analysis of randomized controlled trials. Indian Pediatr 2010, 47:67-73.

doi:10.1186/1471-2334-14-S1-S3

Cite this article as: Berti et al:: Tuberculosis in childhood: a systematic review of national and international guidelines. BMC Infectious Diseases 2014 14(Suppl 1):S3. 